\title{
Workers' Control and Militancy in an Iowa Labor Movement: The Use of Wildcat Strikes at the Des Moines Firestone Tire and Rubber Company, 1950-1959
}

\author{
HEATHER J. STECKLEIN
}

TO CURB AN OUTBREAK OF STRIKES that began during World War II, the U.S. Congress approved the Labor Management Relations Act of 1947, better known as the Taft-Hartley Act. Legislators on both sides of the aisle, reasoning that TaftHartley would encourage workers with complaints against their employers to forgo wildcat strikes in favor of contractual grievance processes, overrode President Truman's veto of the legislation. Federal statutes created under the act held unionized workers liable for financial losses their companies accrued during walkout strikes. Surprisingly, workers in a variety of American industries actually increased their wildcat striking activity during the decade following the act's adoption. ${ }^{1}$ Employees at the Firestone Tire plant in Des Moines, Iowa, exemplified this trend. Despite the threat of federally sanctioned legal retribution from their employer, members of the United Rubber, Cork, Linoleum, and Plastic Workers of America, Local 310, initiated a large number of wildcat strikes during the 1950s. An

1. George Lipsitz, Rainbow at Midnight: Labor and Culture in the 1940s (Chicago, 1994), 168-70, 182.

THE ANNALS OF IOWA 63 (Summer 2005). (C) The State Historical Society of Iowa, 2005. 
analysis based largely on oral interviews from the Iowa Labor History Oral Project suggests that workers used wildcat strikes as a quick way to address immediate problems. The wildcat strikes at the Des Moines Firestone plant supplemented the slower, less successful arbitration process outlined in the union's contract with Firestone.

THE 1947 TAFT-HARTLEY ACT amended the National Labor Relations Act of 1935 (or Wagner Act). The Wagner Act had cemented the right of workers to unionize, bargain collectively, and strike. Consequently, unions felt secure instigating strikes to draw attention to their concerns about wages, pay rates, work hours, and working conditions. ${ }^{2}$

Throughout the 1930s and early 1940s, unions deployed strikes as vehicles for coercing employers into resolving grievances swiftly. To ensure labor cooperation in the war effort, President Franklin Roosevelt announced on January 12, 1942, the creation of the National War Labor Board (NWLB). In response, the American Federation of Labor (AFL) declared that its members would follow a no-strike pledge for the duration of the war. The Congress of Industrial Organizations (CIO) soon followed suit, and its members endorsed the no-strike pledge at each of its annual conventions during the war. With notable exceptions in the auto and coal industries, American workers followed these resolutions, and unions decreased their striking activity significantly during the war years. ${ }^{3}$

Such stabilization depended entirely on workers' wartime loyalty. As economist Harold Davey observed, "After V-J Day,

2. Holly J. McCammon, "Disorganizing and Reorganizing Conflict: Outcomes of the State's Legal Regulation of the Strike since the Wagner Act," Social Forces 72 (1994), 1020, 1012.

3. Harold W. Davey, Contemporary Collective Bargaining (Englewood Cliffs, NJ, 1959), 3; James B. Atleson, "The Law of Collective Bargaining and Wartime Labor Relations," in American Labor and the Era of World War II, ed. Sally M. Miller and Daniel A. Cornfield (Westport, CT, 1995), 46; Rick Fantasia, Cultures of Solidarity: Consciousness, Action, and Contemporary American Workers (Berkeley, CA, 1988), 51; Robert H. Zieger, American Workers, American Unions (Baltimore, 1994), 104. Atleson notes that workers in the automobile and coal industries actually increased strike activity during World War II, as does Seymour Martin Lipset, ed., Unions in Transition: Entering the Second Century (San Francisco, 1986). 
the lid blew off." 4 Workers in industries such as steel, rubber, and meatpacking once again expressed their grievances by instigating strikes. General Motors workers initiated one of the most notable strikes in the postwar period. Following a series of smaller strikes addressing wartime grievances, more than 200,000 GM workers left their jobs on November 21, 1945, and did not return to work until mid-March. ${ }^{5}$ That strike was part of a larger trend among American workers. In the massive strike wave that followed in 1946, American factories lost over 113 million man-days of work to strikes. ${ }^{6}$

Legislators scrambled to develop a way to keep worker militancy in check, and the Taft-Hartley Act was their legislative solution. "In essence," writes Harold Davey, "the Taft-Hartley Act represented a conviction that free collective bargaining had failed." As the economy readjusted to non-military production, many Americans grew concerned about the possibility of another depression. In a January 1947 Newsweek poll, nearly 70 percent of respondents indicated that they expected a depression within the next ten years. The loss of economic revenue during strikes became a target for concerned members of the public, and legislators began to decry worker militarism. Congressional conservatives who traditionally espoused limited government involvement in the economy now supported TaftHartley as an opportunity to keep the system stable. Likewise, liberals such as Jesse Jones and Paul Hoffman thought that new controls on labor were necessary to ease the transition back to a consumer economy. Liberal representative Harold Stassen of Minnesota declared that "the right to strike must be maintained" but used sparingly, "like the right to shoot in self-defense." 7

Taft-Hartley garnered the support of more than two-thirds of Congress and passed over President Truman's veto. The act

4. Davey, Contemporary Collective Bargaining, 48.

5. Nelson Lichtenstein, Labor's War at Home (New York, 1982), 225-26.

6. Sumner H. Slichter, "The Taft-Hartley Act," Quarterly Journal of Economics 63 (1949), 7, defines a man-day as "the amount of work one worker was expected to accomplish in eight hours," and notes that the loss of man-days in 1946 was three times the previous high mark set in 1937.

7. Davey, Contemporary Collective Bargaining, 49; Lipsitz, Rainbow at Midnight, 168,169 . 
contained a variety of legal restrictions designed to curtail union power. A particularly significant component expanded employers' access to federal courts for lawsuits against their unions. Before Taft-Hartley, employers had limited opportunities to bring cases against unions to federal jurisdiction. Now, since many unions failed to negotiate no-strike clauses out of their contracts, companies could sue striking unions in federal courts for breach of contact. In court, proof of union involvement in strikes could make locals liable for damages that the company accrued during wildcat strikes. Employers took advantage of their new access to federal courts immediately. Within the first year after Taft-Hartley passed, 32 companies brought federal suits against their unions. ${ }^{8}$

The Taft-Hartley Act marked just one instance in a long string of attempts by plant owners and government officials to control the behavior of workers and optimize their output. Labor historians and social scientists have investigated how workers resisted initiatives by their employers to systematize their plants. They have described how workers responded to issues such as mechanization, scientific management, and layoffs; detailed how the corporate welfare structure implemented in plants in the 1920s contributed to the breakdown of cultural segmentation among workers and led to the rise of CIO unions in the 1930s; and investigated why work stoppages such as wildcat strikes occurred frequently in post-World War II American industries. Sociologist James Zetka Jr. defined wildcat strikes as instances when "workers shut down production on their own initiative to force a resolution of their grievances directly on the shop floor without official union support or mediation." 9

Since wildcats were, by definition, independent of unions, some scholars have misjudged the practice of wildcat striking as a sign of union impotence. Walter. Galenson contended that the "instability of industrial relations, characterized by wildcat strikes

8. Slichter, "Taft-Hartley Act," 16; Edwin Witte, "An Appraisal of the TaftHartley Act," American Economic Review 39 (1948), 375.

9. David Montgomery, Workers' Control in America (New York, 1979); Lizabeth Cohen, Making a New Deal: Industrial Workers in Chicago, 1919-1939 (New York, 1990), esp. chaps. 4, 7, and 8; James Zetka Jr., Militancy, Market Dynamics, and Workplace Authority: The Struggle over Labor Process Outcomes in the U.S. Automobile Industry, 1946 to 1973 (Albany, NY, 1995), 215. 
... is a manifestation of union weakness. American trade unions have been important allies of capitalism. They have helped eliminate extremism." Similarly, Herman Benson affirmed that as unions increase in power, "the social weight of the rank and file falls." Galenson and Benson reasoned that workers would avoid militant action if their unions had authority. ${ }^{10}$

In claiming that wildcats proved union weakness, Galenson and Benson overlooked the option adopted by the United Rubber, Cork, Linoleum, and Plastic Workers, Local 310. The unionized workers at the Des Moines Firestone Rubber and Tire plant viewed wildcat strikes as vital supplements to their formal arbitration process. In a 1982 interview Firestone worker Lawrence Russell affirmed, "There's an awful lot of things in our collective bargaining if it hadn't been for the wildcat strikes we couldn't have had. ... I think if we hadn't had them we'd been worse off than we are today." 11

Wildcats were often quick and effective, but they also provided workers with a sense of control over their own destinies. National surveys of workers in the late 1940s and early 1950s indicated that wildcat strikes provided an important psychological release for workers. A study performed by the U.S. Department of Labor in 1950 concluded that many workers used wildcat strikes to actively participate in concerns they found pressing or provoking. Many laborers were content to let union leaders negotiate official issues such as wages, but respondents saw working conditions and respect from management as per-

10. Walter Galenson, "The Historical Rule," in Unions in Transition, 72; Herman Benson, "Union Democracy," ibid., 345.

11. Lawrence Russell, interview by Merle Davis, 9/23/1982, transcript, Iowa Labor History Oral Project (ILHOP), State Historical Society of Iowa, Iowa City. The Des Moines Firestone workers' attitudes are consistent with scholarship that suggests that wildcat strikes offered legitimate options for resistance among union members. According to Rick Fantasia, Cultures of Solidarity, 231, a "wildcat strike essentially represents a form of grievance resolution independent of routinized grievance practices that are viewed as ineffectual, and thus it has an 'offensive' character, at the same time as it implicitly reaffirms and defends the established rights of grievance resolution." Similarly, Robert Zieger, American Workers, American Unions, 156, posited that although unions worked to resolve many issues through the arbitration process, workers often found formal processes too slow to address the daily problems (such as shop fans or other minor safety matters) workers encountered. Consequently, workers initiated work stoppages to quickly resolve high-priority problems. 
sonal issues. In 1955 an auto assembly line worker related why he and his coworkers walked out when management fired an employee in his department: "Somehow that guy was every one of us. ... I think that the thing that will drive a man to lose all that pay [during a walkout] is deeper than wages." 12

WORKERS IN THE IOWA LABOR MOVEMENT exhibited remarkable militancy in the years following Taft-Hartley. Meatpacking workers in Ottumwa engaged in so many militant actions in the years after World War II that in 1948 the exasperated national president of John Morrell and Company, George Morrell Foster, remarked, "Our experience with the Ottumwa local has been bad. Within the past five years there have been 42 work stoppages, slowdowns, or strikes resulting in 67 days lost." A worker who started at the plant in 1949 observed that the existing workforce walked out so often that he saw the wildcats as frivolous. By contrast, the workers who initiated the wildcats saw them as essential components of the negotiation process. Union member Virgil Bankson insisted that meatpackers at the Ottumwa plant needed to use militant walkouts, and sometimes physical violence, to maintain the respect and attention of management. ${ }^{13}$

Workers at both the Ottumwa Morrell plant and the Des Moines Firestone plant credited their radicalism to the influence of the large number of their coworkers with coal mining backgrounds. At its peak in the 1930s, the United Mine Workers District 13, headquartered in Albia, Iowa, included more than 20,000 members who commonly participated in radical activity. Morrell meatpacker Edward Filliman recounted his father's radical activities and noted that they got him "kicked out of a company house in a mining town." 14 Firestone employee Frank Grant, who began his career as a coal miner in Prairie City, Iowa, recalled that "whenever something came up," his coworkers would dump their drinking water so that they needed to return

12. Lipsitz, Rainbow at Midnight, 232.

13. Wilson J. Warren, Struggling with "Iowa's Pride": Labor Relations, Unionism, and Politics in the Rural Midwest since 1877 (Iowa City, 2000), 71, 78.

14. Ibid., 79. 
to the surface. They would then walk away from the worksite until the issue was resolved. Grant contended that the miners saw each other's problems as mutual and would initiate work shutdowns as a group. Another Firestone employee, Lawrence Russell, declared, "You didn't debate it down there in the mine. You walked out." 15

Militant coal miners played a central role in organizing $\mathrm{CIO}$ member unions throughout the Midwest. After coal mines closed in large numbers during the 1930s and 1940s, miners fanned into other industries and spread radical ideas to their new workplaces. When the United Rubber Workers of America (URW) formed on September 12, 1935, in Akron, Ohio, it relied heavily on members from coal mining backgrounds. A 1956 history of the organization proclaimed that the URW was "born in the minds of union coal miners and the sons and daughters of union coal miners who came from West Virginia and Southern Ohio, Indiana and Illinois, to work in Akron rubber shops." 16 Soon after the Committee (later Congress) of Industrial Organizations (CIO) formed in November 1935, the URW became a loyal member union. The URW aggressively organized District 4, which included Illinois, Iowa, Wisconsin, Kansas, Nebraska, and Oklahoma. During its first 20 years, district organizers created 50 local unions with 27,000 active members. ${ }^{17}$

The militant actions of unionized workers in Iowa led to legal suits against their unions. The United Electrical Workers union at the Oliver Tractor Works in Charles City suffered for its workers" "panther hunt." In 1951 a hunter sighted a black panther near Charles City. The next day, frustrated workers in the foundry area of the Oliver Tractor Works read a newspaper account about the animal. To punish the company for its failure to respond to their wage rate complaints, they initiated a wild-

15. Frank Grant Jr., interview by Merle Davis, $9 / 15 / 1982$, transcript, ILHOP; Russell, interview.

16. Education Department, United Rubber, Cork, Linoleum, and Plastic Workers of America, AFL-CIO, "We Dared to Dream: The Story of the Rubber Workers' Union and the Men and Women Who Built It" (1956), 6, box 4, folder 4, United Rubber, Cork, Linoleum, and Plastic Workers of America, Local 310, Records, 1950-1972, State Historical Society of Iowa, Iowa City (hereafter cited as URW 310 Records).

17. Ibid., 22. 
cat strike. The workers referred to their strike as a panther hunt, and joked that they were taking time off of work to hunt the wild cat. The walkout quickly escalated into a full-blown twoweek-long illegal strike. Charles City worker Delbert Vokes recalled, "We couldn't call it a legal strike, because we hadn't posted notice ... but everyone decided to go hunt that panther. So we all went out hunting right here on 13th street" (where the union put up its picket signs). With evidence of a clear union violation of the no-strike agreement, the Oliver Tractor Works sued the national United Electrical Workers union for hundreds of thousands of dollars in damages. The local chapter of the union paid a portion of the settlement by allocating a quarter of its monthly dues to the company. ${ }^{18}$

Following Taft-Hartley, unions employed two different strategies to escape legal liability for the strikes their workers incited. The first technique was exhibited mainly by coal miners in Pennsylvania and Alabama. For three months, those workers initiated a series of widespread wildcat strikes. Their actions rendered the industry so helpless that managers were willing to renegotiate their contracts with the unions. The new contracts stated that the coal miners would only be required to come to work when they were "willing and able to work." 19 Once the miners secured the contractual right to come and go as they pleased, wildcats could no longer harm them financially.

The second, more popular method to avoid liability was to rewrite strike clauses in contracts with companies. At the onset of Taft-Hartley, 95 percent of American unions maintained nostrike pledges in their contracts. ${ }^{20}$ When new contract negotia-

18. Clement Kilby, interview by Merle Davis, 6/18/1982, transcript, ILHOP; Delbert Vokes, interview by Merle Davis, 6/15/1982, transcript, ILHOP; Donald Krinkie, interview by Merle Davis, 6/14/1982, transcript, ILHOP; Harris, interview; Perry Chapin, interview by Merle Davis, 10/7/1982, ILHOP. While questioning Chapin, Merle Davis mentioned details of the panther hunt, including the name of the plant in Charles City and that it occurred in the 1950s. Don Harris indicated in his interview that, about three years later, during negotiations for a new contract, the union persuaded the company to end the payments. Harris, the UE's district president, also indicated that he originally placed the responsibility for repayment on the local union in order to avoid full payment.

19. Lipsitz, Rainbow at Midnight, 182.

20. McCammon, "Disorganizing and Reorganizing Conflict," 1018. 
tions arose, many unions insisted on clauses that limited their legal liability to strikes that the union specifically called. The United Auto Workers signed a contract that banned any strike that was not authorized by the international union. Thus, management could punish individual workers for wildcats, but could not drain the UAW treasury with lawsuits. ${ }^{21}$ Other unions made attempts to eliminate the no-strike provision from their contracts altogether. After Taft-Hartley became law, the AFL urged all of its member unions to refuse all contracts with no-strike clauses. United Mine Workers president John L. Lewis went one step further and negotiated a contract that not only absolved the union of responsibility for strikes, but also dissolved the contract when miners were unwilling or unable to work. 22

WHEN UNITED RUBBER WORKERS LOCAL 310 became a member group of the CIO in 1945, it adopted the compulsory wartime no-strike pledge. The United Rubber Workers began organizing the Des Moines Firestone plant when its first workers were hired on February 27, 1945. The union gathered a strong contingent of members among the plant's first $250 \mathrm{em}$ ployees, and it won the plant's certification election seven months later. The United Rubber, Cork, Linoleum, and Plastic Workers of America, Local 310, received its charter in October 1945.23

Local 310 members recognized former coal miners as leaders in the organizing process. Lawrence Russell described the role of coal miners in the early formation of the union: "The company hired a couple of guys back early in 1945 that had been foremen in the coal mines, because the coal mines were being shut down. When they got in here as foremen, they went out and hired their buddies from Melcher and Madrid [coal mining towns]... . [A] lot of the miners came and brought their union philosophy with them. ${ }^{24}$

21. Lipsitz, Rainbow at Midnight, 183.

22. Witte, "Appraisal of the Taft-Hartley Act," 375.

23. "History of Local $310^{\prime \prime}$ (1963), 1, box 4, folder 4, URW 310 Records.

24. Russell, interview. 
Many of the employees who did not come to Firestone directly from mining had grown up in mining communities. Workers at Firestone observed that over half of the employees at the Des Moines plant were either former miners or the descendants of miners. Firestone employees Irene Tantillo, Chester Johnson, Frank Grant Jr., and Chester Turpen all mentioned their fathers' work as coal miners. Don Harris believed that coal mining fathers imbedded their radicalism "into the minds and souls" of their children. As evidence of his father's devotion to the national coal mining union, Robert Bianchi quipped, "We prayed to God and [United Mine Workers president] John L." 25

After Taft-Hartley, Local 310 joined the ranks of unions who failed to successfully negotiate contracts without no-strike clauses. Worker Perry Chapin recalled that Local 310 always faced an element of danger when workers struck because the no-strike clause in its contact made it vulnerable to retribution. Lawrence Russell recalled the potential legal dangers to a union with wildcatting members. "We've had a no-strike clause in our agreement for a long time. We [sic] talk about a violation of the collective bargaining agreement, and later with Taft-Hartley it became illegal under the law." 26

In theory, the combination of Taft-Hartley legislation and contracts with no-strike clauses set the stage for a lawsuit between striking URW 310 members and the Des Moines Firestone plant. That legal framework, along with successful lawsuits against other Iowa unions for wildcats, could have dissuaded Firestone workers from participating in wildcat strikes. However, the Des Moines Firestone plant avoided litigation against its union throughout the 1950s. Workers from URW 310 recounted that they did not consider Taft-Hartley a threat. Ivan Speer noted, "On our walkout wildcats, we could [have] cared less about Taft or Hartley, either one. We just went on and walked out." Lawrence Russell affirmed, "It was probably six or seven years before anybody really knew what the impact of

25. Irene Tantillo, interview by Greg Zieren, 2/20/1980, transcript, ILHOP; Grant, interview; Chester Turpen, Chester Johnson, and John Liddicoat, interview by Greg Zieren, 2/2/1980, transcript, ILHOP; Harris, interview; Robert Bianchi, interview by Merle Davis, 8/28/1982, transcript, ILHOP.

26. Chapin, interview; Russell, interview. 
it was. So we were pretty much free to deal as we wanted without fear of anything happening to us." 27

Workers at the Des Moines Firestone plant resolved many of their grievances through wildcat work stoppages. Throughout the 1950s, Local 310 members called dozens of wildcat strikes and gained a reputation for radical action. For months in the 1950s, Stan Eckert, who started at Firestone in the 1960s, recalled watching his father return home from Firestone in the middle of the day "more times than he didn't." Wildcats kept another worker away from the plant for so many days that the sandwich he had prepared for his lunch went bad. Union member Chester Johnson mused that wildcats occurred "day after day, month after month" in 1954, 1955, and 1956; and Richard Dawson noted that "in them days, very few months went by that you didn't have one or two [wildcats]." 28

The workers' disregard for potential legal retribution was also evident in the brazenly illegal acts of union leaders on the shop floor. Union stewards participated in the Des Moines Firestone plant's wildcat strikes in a way that exposed URW Local 310 to a risk of litigation. Economist William H. Leahy outlined two mistakes union stewards could make during wildcat strikes that would put the union at increased risk for legal retaliation. First, he asserted that it was dangerous for union stewards to participate in wildcat strikes. If they walked out of the plant with the other workers, the company had grounds to implicate the union for contributing to the action. Similarly, he maintained that union stewards projected tacit union endorsement of wildcats when they did nothing to prohibit their execution. Leahy noted instances where courts had cited each kind of behavior to find in favor of the company. ${ }^{29}$

Union stewards at the Des Moines Firestone plant commonly participated in the behaviors Leahy discouraged. Often,

27. Ivan Speer, interview by Greg Zieren, 2/26/1980, transcript, ILHOP; Russell, interview.

28. Stan Eckert, interview by Merle Davis, 9/17/1982, transcript, ILHOP; Richard Dawson, interview by Merle Davis, 9/15/1982, transcript, ILHOP; Turpen, Johnson, and Liddicoat, interview.

29. William H. Leahy, "Arbitration, Union Stewards, and Wildcats," Arbitration Journal 24 (1969), 53-55. 
they either acquiesced or participated directly in wildcat walkouts. Employee Ivan Speer contended that union stewards routinely looked the other way during wildcats and did not try to convince workers to return to their work stations. Union steward Lawrence Russell recalled, "I more than once have told people that they couldn't walk out of the plant, that their contract said that they take it through the grievance procedure, and [at] the same time pointing at the damn gate." 30

Several factors may have prevented Firestone from taking legal action against its workers in the first decade of TaftHartley. One was the strong cohesion among workers during their illegal wildcat strikes. Sociologist James Zetka Jr. and economist Sumner H. Slichter contended that wildcatters were extremely dependent on their fellow employees. Zetka affirmed that unless there was complete participation in wildcat strikes, instigators risked being conspicuous enough to lose their jobs. Once workers emptied the plant, they had genuine power over management. Slichter stated that the threat of extended strike activity from a force with strong worker solidarity often coerced a company into resolving grievances swiftly. ${ }^{31}$

Workers at the Des Moines Firestone plant orchestrated successful plantwide strikes throughout the 1950s. When wildcats spread through the plant, many workers participated enthusiastically. Tire builder Richard Dawson noted that once one department left the plant, others soon followed. When a worker entered Dawson's department and announced that the truck tire section had walked out, he and his coworkers reasoned, "Well, if they're out, we're going." Lawrence Russell noted that workers in the fifties followed the lead of the instigator: "Whatever his reasons was, that's good enough for me." 32

The tendency toward militancy in the plant was not universal. Some voices of dissent against walkouts felt coerced into participating in the demonstrations. As they recollected their participation in wildcat strikes, workers Irene Tantillo and Chester Johnson detailed the ways that a radical minority in-

30. Speer, interview; Russell, interview.

31. Zetka, Militancy, Market Dynamics, and Workplace Authority, 215; Slichter, "Taft-Hartley Act," 2-3.

32. Dawson, interview; Russell, interview. 
timidated them into participating. Tantillo asserted that there were radical workers at the plant that she "just couldn't reason with." When these workers called for wildcats, she encouraged them to use the formal grievance procedure, but "they were hotheaded" and preferred to incite illegal actions. Likewise, Chester Johnson characterized the instigators as "four men out of a group of fifty or sixty" "who coerced the other workers into participating in wildcat strikes. "Lots of times we knew that these fellows were in the wrong," contended Johnson, but workers "didn't want these guys against them" because "they would slash your tires." He lamented, "They'd do anything out there in the parking lot if you opposed them." 33

Compulsory overtime and long shifts also contributed to the plant's reluctance to bring its workers to court. The arbitration record for Grievance 468 in 1953 stated that workers at the Des Moines plant were working seven days per week, with one day off in each cycle. Furthermore, the record indicated that during the month of March the company scheduled the complaining employee for 13 eight-hour shifts, 1 sixteen-hour shift, and 4 twelve-hour shifts. ${ }^{34}$ Doran Reed recalled that workers at the Des Moines Firestone plant worked so many overtime shifts that they made decent pay despite their wildcats. Similarly, Lawrence Russell described the overtime schedule at Firestone: "I had a brother-in-law that had a good job in 1954, which would be considered by most guys a good job. I was on strike all summer, with these two big legal strikes and all these illegal strikes, but when we got to year's end I had made more money than he had, because ... I was working Saturdays and Sundays and overtime." 35 Within this context of double shifts and weekend overtime, the Firestone plant may have resisted taking its union to court for two reasons. First, its questionable hour requirements for workers may have put it at risk for legal action. In addition, wildcats were less detrimental to a plant with extended shifts than a plant with standard work weeks and shifts.

33. Tantillo, interview; Turpen, Johnson, and Liddicoat, interview.

34. "Decisions of the Impartial Arbitrator," 3/26/1953, box 1, folder 3, URW 310 Records.

35. Doran Reed, interview by Merle Davis, 10/11/1982, transcript, ILHOP; Russell, interview. 
Although worker solidarity, productivity, and compulsory overtime may have prevented the Des Moines Firestone plant from suing its workers in its first decade under Taft-Hartley, the company made a few attempts to take disciplinary actions to keep its workers in check. Firestone tried to control its workers with suspensions and firings during the 1950s, but ultimately those actions were fruitless. Management's attempts to alter employee militancy led to more of the behavior the company sought to discourage. In 1958 the plant fired all of the tire builders in a department for inadequate production rates. In response, workers shut down the entire plant for nearly a week until the company agreed to rehire their coworkers. Similarly, when the plant tried to govern its workers with suspensions, employees instigated wildcats to slow production until the suspended workers returned. In 1953 the president of Local 310 reported, "The company has suspended about 20 tire builders for a period of one week, as a result, the rest of the tire builders have taken a seven day suspension. ... The plant, for all practical purposes, is not in operation." 36

ALTHOUGH THEIR CONTRACTS outlined a formal process for resolving grievances, the workers at the Des Moines Firestone plant preferred wildcats to resolve grievances that they feared would stagnate during the long arbitration process. As in 90 percent of union contracts during the 1950s, URW Local 310 adopted compulsory arbitration as the final step of its grievance process with Firestone. Within that system, the union and the employer adopted a contractual provision to voluntarily arbitrate grievances. Under that provision, union members and company representatives agreed to meet with an impartial third party to resolve problems and to accept the arbitrator's decision as binding. ${ }^{37}$

Firestone workers believed that the third-party arbitrators failed to adequately address their grievances. The contracts be-

36. Dawson, interview; Russell, interview; President, Local 310, URCLPW, to Floyd Robinson, 5/23/1953, box 2, folder 1, URW 310 Records.

37. Davey, Contemporary Collective Bargaining, 136; Arbitration hearings, box 1 , folders 1-9, URW 310 Records. 
tween URW Local 310 and Firestone used judicial arbitrators, who were consistently preferred by employers. These arbitrators assumed that the union and Firestone had agreed to disagree. Consequently, they declared decisions in favor of one party or the other. Labor historian Harold Davey described the implications of judicial arbitration for unions. According to Davey, unions preferred the "split the difference" approach to arbitration processes where arbitrators mediated negotiations between parties. Perry Chapin summed up the union members' disdain for the arbitrator's decisions: "You never knew what the arbitrator was going to come back with." 38

Many members of Local 310 considered the contract's grievance process a fool's errand. In a 1982 interview, Lawrence Russell claimed that whenever outsiders suggested using the arbitration process, workers laughed at them. The union was justified in its cynicism toward the process. In cases when the union arbitrated its grievances, it consistently lost more cases than it won. Of the nine cases arbitrated in 1951 and 1952, the arbitrator only found for the union twice. ${ }^{39}$

Because the arbitration process tended to resolve in the company's favor, Firestone often refused to preempt arbitration hearings with negotiations. According to the contracts between the union and the company during the 1950s, the union and the company were to meet for negotiations and resort to arbitrations only as a last resort. ${ }^{40}$ In 1953 the Local 310 president wrote to another local about his problems getting the company into negotiations: "I believe that you are aware of the situation in Local \#310 - that Firestone Tire and Rubber Co. is not willing to settle any negotiations short of arbitration." Four years later,

38. Davey, Contemporary Collective Bargaining, 138-39; Chapin, interview. At the end of every arbitration decision in the Local 310 Records, the arbitrator declares in favor of either the union or the company. Arbitration hearings, box 1, folders 1-10, URW 310 Records.

39. Russell, interview; "Decisions of the Impartial Arbitrator," 6/20-21/1951 and 1/3-4/1952, box 1, URW 310 Records. In two cases regarding work rates, the arbitrator ruled that the union and the company should each retest the rate and reach a compromise.

40. Grievance 403, arbitration hearing 3/26/1953, box 1, folder 8 , URW 310 Records. At this hearing, workers stated that they had unsuccessfully gone through negotiation as one of the prescribed steps of the grievance process. 
a letter from the Local 310 president to the URW district director confirmed that the union continued to experience frustration with the company's repeated rejection of negotiation opportunities: "We have tried about a dozen times in meetings with the company to resolve this issue short of arbitration, but the company has stubbornly refused to settle in any other manner." 41

While the unbalanced results of arbitration hearings concerned the union, delays in the process caused even more problems. Once grievances became part of the arbitration docket, months and sometimes years passed before they reached discussion. Every 90 days, URW Local 310 cataloged its grievances with the company and notified the company of which complaints it wished to keep active. Often, since the original reason for a grievance no longer existed by the time the complaint reached discussion, the grievance disappeared from contention. Lawrence Russell stated that a grievance involving a certain type of tire would disappear from the grievance catalog when the plant stopped producing the model. He noted that if the factory resumed production of that same model two years later, the union would place the old grievance back on the docket. ${ }^{42}$

Even when grievances did not become dormant by changes in production, the process required an extended period of time. In 1953 the URW 310 president complained that delays in the process left a set of grievances "pending for a considerable amount of time." 43 Of the grievances that reached arbitration in March 1953, the original filing dates ranged between March 1952 and January 1953.

Because the arbitration process delayed the resolution of grievance for months and often resolved in favor of Firestone, Local 310 limited its arbitrated grievances to a small number without immediate importance. Between 1950 and 1955, Local 310 and Firestone met with arbitrators at the Hotel Savery on at least seven occasions. Of the grievances resolved in these arbi-

41. President, Local 310, URCLPWA, to Floyd Robinson, 12/2/1953, box 2 , folder 1, URW 310 Records; James T. Caffrey to Floyd Robinson, 1/31/1957, ibid.

42. Russell, interview.

43. President, Local 310, URCLPWA, to Floyd Robinson, 12/2/1953, URW 310 Records. 


\section{TABLE}

SUMMARY OF ARBITRATION HEARINGS

EXECUTED BETWEEN UNITED RUBBER WORKERS LOCAL 310 AND

THE DES MOINES FIRESTONE TIRE AND RUBBER COMPANY, 1950-1953

\begin{tabular}{|c|c|c|}
\hline No. & Date & Cause/Decision, if recorded \\
\hline 106 & $2 / 13 / 1950$ & $\begin{array}{l}\text { Unfair loss of seniority for transfer of union worker/ } \\
\text { Decided in favor of Firestone }\end{array}$ \\
\hline 139 & $\begin{array}{l}6 / 20-21 / \\
1951\end{array}$ & $\begin{array}{l}\text { Workers' piece rates are unfairly distributed/ } \\
\text { Decided in favor of Firestone }\end{array}$ \\
\hline 59 & $\begin{array}{l}6 / 20-21 / \\
1951\end{array}$ & $\begin{array}{l}\text { Workers paid the same for tubing out heavier tread/ } \\
\text { Decided in favor of Firestone }\end{array}$ \\
\hline 130 & $\begin{array}{l}6 / 20-21 / \\
1951\end{array}$ & $\begin{array}{l}\text { Rate assigned to automatic tire workers too fast/ } \\
\text { Union and Firestone instructed to compromise }\end{array}$ \\
\hline 175 & $\begin{array}{l}6 / 20-21 / \\
1951\end{array}$ & $\begin{array}{l}\text { Rate assigned to } 12-18 \text { O.C. tire unattainable/ } \\
\text { Union and Firestone instructed to compromise }\end{array}$ \\
\hline 44 & $\begin{array}{l}6 / 20-21 / \\
1951\end{array}$ & $\begin{array}{l}\text { Lead hammer supplied to workers caused undue strain/ } \\
\text { Decided in favor of Firestone }\end{array}$ \\
\hline 62 & $\begin{array}{l}6 / 20-21 / \\
1951\end{array}$ & $\begin{array}{l}\text { Employee transferred and not paid according to seniority/ } \\
\text { Decided in favor of Firestone }\end{array}$ \\
\hline 212 & $\begin{array}{l}1 / 3-4 / \\
1952\end{array}$ & $\begin{array}{l}\text { Workers unable to make base rate due to conditions } \\
\text { beyond their control/Decided in favor of Firestone }\end{array}$ \\
\hline 19 & $\begin{array}{l}1 / 3-4 / \\
1952\end{array}$ & $\begin{array}{l}\text { Worker misled into taking a job that was not full time/ } \\
\text { Decided in favor of Firestone }\end{array}$ \\
\hline 301 & $\begin{array}{l}1 / 3-4 / \\
1952\end{array}$ & $\begin{array}{l}\text { Company set up department that discounted seniority/ } \\
\text { Decided in favor of Firestone }\end{array}$ \\
\hline & $\begin{array}{l}1 / 3-4 / \\
1952\end{array}$ & $\begin{array}{l}\text { Worker not allowed back to work due to illness, although } \\
\text { physician says he is fine/Decided in favor of the union }\end{array}$ \\
\hline 336 & $3 / 24 / 1953$ & $\begin{array}{l}\text { Non-union employees working at tool crib on weekends/ } \\
\text { Decided in favor of Firestone }\end{array}$ \\
\hline 346 & $3 / 24 / 1953$ & $\begin{array}{l}\text { Supervisor yelled at worker for a half-hour, then refused } \\
\text { to pay him for the time }\end{array}$ \\
\hline 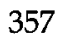 & $3 / 25 / 1953$ & Worker held responsible for his replacement's mistake \\
\hline 04 & $3 / 25 / 1953$ & Company changed a position title outside of contract \\
\hline & $3 / 26 / 1953$ & Worker wants half-hour of pay for using sticky stock \\
\hline 459 & $3 / 26 / 1953$ & Workers improperly paid for their piecework \\
\hline$\$ 68$ & $3 / 26 / 1953$ & Employee improperly fired for excessive absenteeism \\
\hline & $3 / 26 / 1953$ & Employee improperly fired for excessive absenteeism \\
\hline & $3 / 26 / 1953$ & Employees improperly reprimanded \\
\hline
\end{tabular}

SOURCE: Arbitration hearings, box 1, folders 1-10, URW 310 Records. 
trations, 12 involved pay rate grievances, 3 dealt with unfair reprimands, 2 involved issues of seniority, and 1 addressed working conditions (see table). ${ }^{44}$ Furthermore, the pay rates brought into question were often retroactive; that is, in many cases, the union sought back wages for payment that had since been resolved by policy changes. ${ }^{45}$ Consequently, arbitrations rarely resolved issues of immediate significance to workers.

Instead, workers used wildcat strikes to resolve their most pressing concerns. Issues involving working conditions commonly caused workers to incite wildcats. According to Lawrence Russell, safety conditions were not among the grievances admissible for the formal grievance process during the 1950s. Despite workers' efforts, the union was unable to add safety conditions to the contract for arbitration until the early 1960s. ${ }^{46}$ Thus, workers often refused to work when conditions in the factory made their work hazardous. Ivan Speer recalled an instance when workers in the already hot curing room faced the additional burden of an Iowa summer. "This was in the hot summertime. ... We wanted fans to circulate the air. [The company answered,] 'No way!'" Richard Dawson recalled, "It'd get up to 100 degrees outside and somebody'd say 'Man, it's too hot to work!" 47

Ivan Speer contended that in many cases, workers walked out because they knew that the company could have easily resolved the issue. He noted that representatives of management often dismissed requests by stating that the company could not afford them. Often, workers issued complaints to the company and issued arbitrary deadlines for the company to respond. If Firestone did not react to the workers' satisfaction, the employees walked out until the resolution met their approval. Doran Reed recalled wildcat actions regarding heat issues: "In the passenger tire room, they eventually put those cool rooms in ...

44. Arbitration hearing, 3/26/1953, transcript, box 1, folder 7, URW 310 Records. 45. See grievances 139 and 159.

46. Russell, interview. One grievance (\#144) could fall into the work safety category. However, this case was not of pressing importance because use of the lead hammer was experimental and optional. The union lost the case in question because workers could use the rubber hammer when they chose.

47. Speer, interview; Dawson, interview. 
but prior to that, they would be asking the company to do something, and if they didn't something like that [wildcat strike] would happen." 48 Workers employed wildcats to quickly resolve issues of immediate importance to them. When the factory became unbearably hot and the company refused to respond, workers left until conditions improved.

WORKERS at the Des Moines Firestone Tire and Rubber Company employed illegal wildcat strikes to gain immediate headway on pressing issues at their plant. Despite a national climate of prosecution for wildcat activity, workers at the Des Moines Firestone plant initiated dozens of walkouts during the 1950s. For most of their concerns, members of URW Local 310 avoided the contractual grievance process because they realized that the arbitration process delayed resolutions and tended to favor the company. Consequently, they reserved formal arbitration for matters such as back wages for unfair piece rates that were not of pressing concern. For more immediate issues such as worker safety conditions, employees initiated work stoppages to force quick responses from the company. The Des Moines Firestone plant made it possible for workers to go out on wildcat strikes by opting not to bring Local 310 to court for damages rendered during strikes. Therefore, workers found illegal strikes to be a safe alternative to the ineffective arbitration process outlined in their contracts. By supplementing the legal grievance process with wildcat strikes, workers at the Des Moines plant ensured quicker, more satisfactory outcomes on a greater variety of their grievances.

As the 1950s yielded to the 1960s, Local 310 increasingly channeled its grievances into formal processes with larger institutions. Local 310 members became active in area union associations such as the Iowa Federation of Labor, the Polk County Labor Council, and the national AFL-CIO. Through such groups, members advocated state and federal legislation to address the issues that commonly incited wildcats. Members of the Iowa Federation of Labor pressured their state representatives to enact stronger laws for unemployment compensation, worker compensation, and

48. Speer, interview; Reed, interview. 
safety regulations. Furthermore, the Polk County Labor Council approached legislators for assistance in defining legal sanctions for worker mental health and disability compensation. ${ }^{49}$

Local 310 members also sought to improve conditions for fellow members by joining and creating community programs. Member James McDonnall joined the Polk County Labor Council Community Services Committee during the mid-1950s. In the ensuing years, he led 14-week courses on community service for URW Local 310 members and other Des Moines unionists. ${ }^{50}$ By the mid-1960s, the Polk County Labor Council had expanded its agenda to address a mix of legislative concerns such as the War on Poverty and community programs such as blood drives, boys clubs, and immunization programs. ${ }^{51}$ By 1970, URW members had significantly altered their perception of how workers should address grievances. In a comprehensive 1970 survey of United Rubber Workers members, less than a fifth of the workers believed that strikes were a viable method for addressing grievances. Rubber workers across the country invested their hope in the possibility of better legislation for pensions, unemployment, and safety standards.52 The era of militancy had ended, and an era of bureaucratization had begun.

49. Iowa Federation of Labor, AFL-CIO, Federation Newsletter, June 1965, box 45, folder 5, Iowa Federation of Labor Records, 1907, 1917, 1934-2000, State Historical Society of Iowa, Iowa City; Polk County Labor Council, AFL-CIO, Newsletter, April 1965, box 28, folder 22, James McDonnall Papers, 1943-1970, State Historical Society of Iowa, Iowa City.

50. Des Moines Register, 3/16/1954, and Des Moines Tribune, 4/19/1955 and 4/16/ 1957, clippings in box 1, folder 12, McDonnall Papers.

51. Minutes, Polk County Labor Council Community Services Meeting, 4/24/ 1965, box 28, folder 22, McDonnall Papers.

52. "Remarks of International President Bommarito to the URW Policy Committee Meeting, 2/5/1970, 6, box 3, folder 1, URW 310 Records. 
Copyright of Annals of Iowa is the property of State of Iowa, by \& through the State Historical Society of Iowa and its content may not be copied or emailed to multiple sites or posted to a listserv without the copyright holder's express written permission. However, users may print, download, or email articles for individual use. 